\title{
Student experience of the University of the Western Cape library: sourcing the problems
}

\author{
D.W. Ruth \\ Department of Industrial and Organizational Psychology, University of the North, Private Bag X1106, Sovenga \\ 0727 Republic of South Africa
}

Received November 1996; accepted June 1997

\begin{abstract}
This article reports on research on the student experience of the library of the University of the Western Cape (UWC). Despite dedicated and hardworking library staff, and lecturers keen that students learn to use the library, efforts to establish effective use seemed to flounder. Due to the nature of the problem, which revolved around experience and perceptions, the phenomenological qualitative research approach was adopted, based on the open question: what is it like using the library? It revealed that many problems which students experience in the library originate elsewhere, such as in general study conditions, design of assignments and curricula content. The importance of the affective aspect of student learning was also made apparent. These findings seem to support the argument that a library education programme needs to extend beyond the library itself, and be a holistic effort entered into by a range of players who are aware of the interrelatedness of the various aspects of student learning. Although this article discusses findings at UWC, both a review of the literature and experience at the University of the North seem to support the argument.
\end{abstract}

Die navorsingsresultate van studente se belewing van die biblioteek van die Universiteit van Wes-Kaap (UWK) word in hierdie artikel weergegee. Ten spyte van toegewyde en hardwerkende biblioteekpersoneel en dosente wat gretig is dat studente die biblioteek leer gebruik, misluk pogings om effektiewe gebruik van die biblioteek te bevorder. Omdat die probleem wentel om menslike ervarings en persepsies word die fenomenologiese kwalitatiewe narvorsingsmetode aangewend. Die ondersoek het aan die lig gebring dat baie probleme wat die studente in die biblioteek ervaar hulle oorsprong elders het, soos in algemene studietoestande, ontwerp van take en kurrikulêre inhoud. Die belangrikheid van die affektiewe aspek van leer het ook duidelik geword. Hierdie bevindinge blyk die argument te staaf dat 'n biblioteekopleidingsprogram verder behoort te strek as die biblioteek self. Sodanige program behoort 'n holistiese benadering te volg. Die rolspelers behoort bewus te wees van die onderlinge verband tussen die verskillende aspekte van die leerproses. Alhoewel hierdie artikel die navorsingsresultate van 'n ondersoek by die UWK reflekteer, word die resultate ondersteun deur 'n literatuurondersoek en ervarings by die Universiteit van die Noorde.

This article reports on research conducted whilst the researcher was an Academic Development Officer at the University of the Western Cape (UWC), and was struck by the fact that despite dedicated and hardworking library staff, and lecturers keen that students learn to use the library, efforts to establish effective use seemed to flounder. Due to the nature of the problem, which revolved around experience and perceptions, a phenomenological qualitative approach was used, beginning with the analysis of essays written in response to the question: what is it like using the library? It became apparent that many problems which students experience in the library have their sources elsewhere, such as in general study conditions, design of assignments and curricula content. The importance of the affective aspect of student learning was also made apparent. These findings seem to support the argument that a library education programme needs to extend beyond the library itself, and be a holistic effort entered into by a range of players who are aware of the interrelatedness of the various aspects of student learning. Although this article discusses findings at UWC, both a review of the literature and experience at the University of the North seem to support the argument.

UWC was established as a 'coloured' university in 1960 with 164 students. In the early eighties its mission was to relate to the development of the third world, change the staff and student profile to reflect the general population profile, democratize governance and focus on curriculum review. The university was wracked by the turmoil of the middle eighties, and then by the rapid transformation of its character. This transformation was led by a specific admissions policy which was developed to change the patterns of access to university education. It was sensitive to a range of criteria such as population group (race), gender, urban to rural provenance, social class and matric group results (Walker \& Badsha 1993).

Given this policy, many students entered university who did not have the 'standard' academic skills required to cope with the university. UWC was now dealing with a student body with a changed language profile, and mostly first-generation students. Although therefore, formal access had been secured, it was clear that actual or 'epistemological access' (Morrow 1992) had to be secured.

To do this, a model of Academic Development (AD) was created which rejected the assumption that the problem was located in the student, and was primarily manifested in communicative, cognitive and subject-specific deficiencies which could be cured through additional tutoring, language courses, foundation years and slow streams (Lazarus 1987 in Walker $\&$ Badsha 1993). The problem was that this allowed business to continue as usual in the rest of the university and functioned as a kind of 'buffer between the university and the black community - a kind of academic group areas' (Mehl 1988:52 in Walker \& Badsha 1993). By 1991 UWC was 
conceptualizing a programme that centred on curriculum development, student learning, staff development and organizational development. Despite this sensitivity and holistic awareness, there were still problems in the library.

In the early 1990s the library suffered a period of poor management. Staff were disaffected and administration was poor. Physically the building is large and attractive, but problems such as noise control, the efficient use of resources and the poor provision of some services were apparent. Like all libraries in South Africa, stocks had been affected by the academic boycott, the exchange control rate, and a steady erosion of subsidies for tertiary education (Koen, personal communication).

Given the climate at UWC described above, a particular issue is intercultural communication, an issue which has become a forceful presence on many white campuses. South Africa's history is marked by lack of intercultural communication skills, and

'the need for library and information workers to study general information skills has not emphasized the additional skills required for cross-cultural communication' (Behrens 1990).

Problems specific to communication between different population groups are: diversity of communication purposes, ethnocentricism, lack of trust, withdrawal, lack of empathy, stereotyping, power, cultural history, role relationships, language, cultural beliefs, non-verbal behaviour, spatial relations and thought patterns.

A danger in South Africa is that librarians, more so perhaps than in other countries, have to deal with the missionary dilemma; are they there to provide counselling or to provide a professional information service?

Cronin and Martin (1983) discuss organizational communication in libraries, pointing out that human failings which cause barriers in communication are probably limitless and they list the five most troublesome general barriers as personality differences, unconscious selective perception, low self-esteem, lack of communication skills and attitudes about communication.

Libraries must also be seen in the larger South African socio-political contexts. Merrett (1988) suggests that South African librarianship has been in crisis for many years. He points to the poor quality of contributions to conferences and journals and suggests that:

'Two emphases, political circumspection and the search for professional stature, have led to an uncritical transfer of management technique and computer technology from the business sector to librarianship ... Libraries are increasingly full of gleaming hardware acquired at enormous cost; but their ability to obtain the fruits of the latest scholarship and investigation in book format is being eroded to a level of disastrous proportion ... Form has triumphed over substance, an alarming trend for a calling whose raison d'etre is founded on service to everyone'.
Certain librarians have confirmed that his (1988:123) claim that 'Librarianship is essential to the educational process yet almost all documented contributions to the profession fail to site it in the current socio-political context' is still valid.

Whilst South African libraries may gain from referring to work elsewhere (Josey 1971; Egerton 1969; Suttie 1990), there are highly specific conditions that must be addressed in tertiary institutions in South Africa. In Merret's paper Walker looks at the need to restructure South African curricula by recognizing the Third World nature of the society for which librarians are being trained and the need to shift resources from the relatively well-provided urban sector to the rural.

Evidence of the importance of the issues raised in this introduction is provided below. The researcher hopes to make it clear that under these conditions any university library in South Africa needs a library education programme and also to show that any library education programme needs to extend beyond the library. Ultimately we end up with the curriculum and the need to design curricula that takes into account actual as opposed to formal access that students have to the institution and the library.

It would seem that two factors militate against the effective use of the library and neither of them originate in the library itself. One is the reliance on prescribed texts and the other is the amount of work that students are expected to 'get through'. The words 'get through' are put in inverted commas because students clearly cannot 'understand', 'process', 'integrate' or do anything similar with the material.

Even endowed with privileged schooling, entering tertiary education is difficult. The teaching and administrative staff have the power and responsibility to make the required changes. Blaming, patronizing or pathologizing students is an abrogation of this power and an evasion of this responsibility.

\section{Research methodology}

The overall process was, briefly, the analysis of a collection of essays, the development of a questionnaire and analysis of answers, a literature survey, and writing up.

I was motivated to employ a qualitative approach by previous research on the first-year experience (Ruth 1993). This revealed large disparities between what staff thought students experienced and what students reported on their experience. Much of the frustration centred on the library.

An open question was distributed to hundreds of students in the Economic and Management Sciences (EMS) faculty: what is it like using the library? These short essays were analysed and a report written and presented to the Faculty and the library. This report served as a basis for several discussions with the subject librarian. On the basis of this.analysis three questionnaires were developed and several hundred distributed. The questionnaires were analysed in conjunction with a literature review. The resulting report was presented to several librarians for discussion. This article records the final results.

The research design was grounded in a qualitative and action-research framework for several other reasons. In 1992 
there had been no systematic enquiry in the EMS faculty into exactly what the problems are that students have in the library, why they have them and what can be done to ameliorate them. Given the context of the enquiry - education in transition with little data on hand - a qualitative research approach (McCracken 1988:49) was adopted. It was thought that the researcher was not yet in a position to seek precise relationships between limited sets of already fixed categories. It still needed to be established what was thought and done in the library. Furthermore, far from being a dispassionate observer, the researcher and other investigators were involved in the library and with students as part of their everyday work. What was required, therefore, was a research methodology that allowed categories and questions to form in the process of the research, and which accessed patterns of relationships between many categories normally hidden from view.

Since the researcher was part of the process it made sense to use action research as another methodological framework. The key points of action research (Kemmis \& McTaggart 1988:22-25 list 17 points) revolve around process and participation, and short-term, small-scale investigations that allow for immediate impact. An action-research approach also made sense given the developmental bias of UWC and the constraints of resources.

The essays were collected from two departments, via tutors. In one department, students clearly wrote in response to a question asking them about problems. The tutors in the other department were specifically briefed to ask the open question 'what is it like using the library?'

More than 700 hundred essays were collected but after reading 200 it was clear that a limit to the range of points that could be made had been reached. In terms of expense of typing and reproduction of essays, it was felt that 100 essays of four tutorial groups gave enough sense, for preliminary enquiry, of the tenor and content of what students thought. Four groups were also enough to indicate an element of group thinking. In the discussion, the numbers in brackets after a statement refers to the number of the essay in a separately published booklet. The analysis of essays led to a report that focussed on noise, availability of material, the computer system and library staff. The essays caused me to question whether students had a concept of information and a sense of strategy, and they indicated a lack of knowledge of basic terms and suggested that further enquiry should focus on basic knowledge and attitudes towards the library, how students learnt about the library, and a more precise identification of the problem points. The essays are numbered and grouped and will be referred to in this text as (14) or (28) or (72a) and so on.

In an attempt to explore these issues and to pursue the overall picture of students' use of the library, three different questionnaires were developed to extend the range of questions. These were distributed across the faculty, broadening the scope of the enquiry. The questionnaires are presented in Appendix A as A, B or C. References in the text will refer to question $\mathrm{A} 2$, or $\mathrm{B} 7$ et cetera. A table of distribution (Appendix B) is also presented.

Although figures are given and percentages will be quoted, these are rough guides to tendencies. This article is not based on statistical analysis. It is a qualitative report.

\section{Basic conceptions of a library}

The basic conception of a library as an issue was suggested by the evidence of the essays. It became clear that students did not look for information - they looked for books, or a paper, or a photocopy. Lecturers perpetuate, through reserved and/or prescribed texts and articles, the belief that only those sources contain the required set of facts needed to pass the course. Thus, the perception of the library as a book warehouse is reinforced.

It is necessary for tertiary level educators in this country to confront the fact that they are not only doing something different to what was done at secondary school, but that they are actually having to counter an entrenched set of attitudes and beliefs and practices about learning and textbooks. Students at school are taught to be rote learners, and text- and teacher-centred. University demands a fundamentally different approach to learning. However, there is much at UWC, and indeed at other Historically Black Universities (HBUs), that reinforces a school approach to learning - talk of classes, homework, prescribing texts, the production of readers, lecturers' use of texts. Yet, when it comes to setting assignments and tests, it is often assumed that students have become autonomous learners. They are told to go to the library and do research.

Lecturers need to work according to realistic assumptions of students' academic competence. When students do not know what a provisional thesis is (14) or the difference between an article and periodical (28), or seem to have a curious notion of referencing (36), they are not going to be able to produce what is expected and they will waste a lot of their own and other people's time in the library. If the students do not understand decimals, let alone the Dewey system, they cannot read the shelves.

This much was apparent from the essays. Reviewing the answers to the questionnaires, it is clear how desperate the need for library education is. A third-year student stated in the questionnaires that she or he still didn't see the point of the Dewey decimal system. About $50 \%$ of the students viewed the library as a bookstore, another $20 \%$ mentioned other materials besides books, and about 50\% mentioned information store. The latter point seemed to contradict my assumption, based on the essays, that students lacked a perception of information. About $25 \%$ saw the library as a study place, and about $20 \%$ as a social place. Only $5 \%$ mentioned research.

In other words, the notion of an organized collection of knowledge, or system of information, was not apparent. This is perhaps not surprising when about a third of the students have no experience of libraries prior to coming to UWC. Those who claim to have little, or only school library 
experience, make up another $20 \%$. This must be seen in the light of the state of many school libraries. For example, in the essays, one student claimed that there were more floors (14) to the UWC library than there were books in the school library. In the questionnaire about a third of the students had negative associations with libraries. Only $12 \%$ mentioned leisure reading.

Most students indicated that they learnt about the library during the orientation week. This consists of a tour - one activity amongst a range of others in the first week. A few mentioned their tutor (where it was a factor in a group, it was never more than $30 \%$ ) and none mentioned a lecturer. In other words, they are not taught how to use the library. The need for them to be taught has implications for curriculum design - if lecturers are going to take the time to teach students how to use the library, they cannot have the same amount of time to 'get through' content.

One curious phenomenon was that in answer to what services does the library offer besides keeping books and journals? (B4) only nine out of 260 mentioned borrowing books. From a student's point of view the major services provided by the library, besides being a bookstore, are interlibrary loans and photocopying. The library fulfills other functions: 'fun to work with your friends' and 'meet people of other cultures'. These are gone into in more detail below. About half of the students use it daily, mainly for studying, because of lack of facilities at home. However, $50 \%$ say they study at home as opposed to residence and another $30 \%$ mention residence (B7). Only 23\% mention the study hall. (Are they told about it?) The use of the library is also directly related to pressure about assignments and tests. De Jager (1991:277), writing about students' use of University of Cape Town library, has also observed this range of library usage:

'Students came into the library not in the first place to use the knowledge of the resources of the library. They came primarily to study and in doing so also made use of recommended works and other library services ... (the students) came to the library not for information services, but for a quiet refuge enabling them to (study) ... (they) used the library as an adjunct to the teaching they receive. They came to the library to process what was being taught'.

She also talks about student accommodation and physical needs.

It would seem then that there is a need to provide basic education about the concept of information, how libraries are generally organized and what for, and about basic library terminology. There is also a need to provide training in elementary research strategies, which is the focus of the next section.

\section{Information-seeking strategy}

The concept of strategy is chosen to relate the different aspects of library usage that emerged in the course of the research. In using the notion of an information-seeking strategy, the concept of information cannot be taken for granted.

We live in an information age, and the major benefit of a tertiary education is the capacity to manipulate information. However, as Cleaver (1987:30) states:

'If students are going to learn to be information users, perhaps we need to provide opportunities for them to think about information itself. We cannot teach students to be effective information seekers and users until they have formulated for themselves some concept of information'.

One view of information common amongst those working in information services is that of information as a definite entity. Others insist that information does not have an independent existence but is rather a construct of the user. It is the former view that dominates amongst UWC students who, like most of the staff, have emerged from a text-centred and teacher-centred education system.

Dervin (in Cleaver 1987:29) and her colleagues have developed a sense-making model which involves three elements: the situation that raises questions; the gap, which might be termed the questions or questioning behaviour; and the use that is made of the answer. However, information systems tend to ask only one question: "what do you want to know?' With respect to information technology and the information society, MacMullin and Taylor (in Cleaver 1987:29) suggest that an information system may be understood in the context of problem dimensions and information traits. There are other equally important concerns besides 'what do you want to know?' that need to be responded to: how do you need to know it? Why do you need to know it? In what form do you need to know it? What do you know already? What do you anticipate finding? There is a difference, they say, in what is contained in the problem and what is contained in the question.

Many curricula at UWC generally fail to recognize the actual competence of students, and even within degree courses they fail to coherently present a progression of knowledge and skills. Most theorists of information acquisition however, present models that have strategic stages and work towards patterns. For example, Blakey and Spence (1990) suggest the following basic metacognitive strategies:

- connecting new information to former knowledge

- selecting thinking strategies deliberately

- planning, monitoring and evaluating thinking processes.

Crow (1992:33) claims that the

'new direction for instruction includes increasing verbal interaction, and developing listening skills, co-operative planning and brainstorming rather than narrow cognitive skills ... Talking through the thinking process involved in researching is an effective way of helping the student develop a pattern of thinking about research problems. Questioning is important in working through a problem'. 
Understanding information, accessing it and using it are sophisticated and demanding activities. The specific problems at HBUs are pointed out by a colleague at the University of the North (Aria Merkestein, personal correspondence):

'I feel that with a dramatic shortage of core knowledge, there's little point in referring students in the first year to the library to do research. I feel ambivalent on even wanting to send students to the library for fear of total confusion. It's only at post-graduate level that I stress the importance of other and critical sources. And even then I have my doubts as to how useful this is. There seems to be such a difficulty for them to contrast definitions, concepts and the like that sometimes the exposure to other sources (too many) adds to chaos.

Often it is purely demotivating for students to be sent to a library of which the internal structure is not accessible either by virtue of the structure itself, or by overloaded curriculum.

The sense of achievement, real achievement, is so underestimated at many tertiary institutions but it is so important.'

\section{Research strategy}

With guidance, the student can learn to recognize her own thinking pattern through a technique of talking about thinking during certain stages of the research activity.

Kulthau (1989:18-25) suggests that the research task consists of stages: to recognize information needs; to investigate information; to gather information for the specific focus; to complete the information search. She emphasized that teachers and librarians 'must allow time for thinking and planning, and have students understand that uncertainty is the beginning of the process', echoing Cleaver's (1987:38) comments that 'students need to learn to tolerate their own uncertainties when the information they encounter is confusing'.

This is even more important in an environment like UWC where, as described above, there are tensions and stress above the usual transition into tertiary education. A particular problem is the quantity of material that UWC expects students to deal with. As an example of the situation at UWC, I recently reviewed the course outlines of a department. In their second year, most students do three subjects. One module (quarter of a year), in this department was divided into nine sections. For one of these sections, the students were directed to readings that totalled nearly 1000 pages. This forces the student into the surface mode of learning and does not allow enough time to develop strategies. Rankin (1988) in his article One route to critical thinking states that two major concerns are time for students to plan a research strategy and time allotted for reflecting on the process after completion of the project.

Staff themselves are under pressure and with staff student ratios of more than 1:500 in some disciplines, they cannot follow what would be an effective sequential teaching strategy such as that suggested by Olsen (1990) which consists of:

- introducing the skill

- explaining the skill

- demonstrating the skill

- applying the skill

- reflecting on the skill

The crux of the issue is: whence and how are students to get the skills they need to progress through the curriculum? Krapp (1988) makes a case for integrating strategies and research skills within the curriculum content and suggests a problem-solving model, which consists of focussing on understanding the problem, planning what to do, verbalizing the procedure and drawing upon prior knowledge. He suggests a systematic thought process that can be applied to future research assignments. According to Crow (1992), findings on critical thinking in the research process suggest certain strategies:

- Make the process relevant by modelling the behaviour in small steps and by talking through the process.

- Make learning an active process; have students involved in planning, evaluating and monitoring by using such strategies as reviewing, journal writing, and questioning.

- Make critical thinking skills relevant by including them in the research process.

Another aspect of the information search process is feelings and attitudes. In Mellon's (1988) research, 75-80\% of students described their initial response to using the library for research purposes in terms of fear or anxiety, a sense of feeling 'lost'. Four reasons for feeling lost emerged: the size of the library; not knowing where things were; not knowing what to do; and not knowing how to begin the research process. According to Mellon, three concepts help to understand library anxiety:

- Students' fears are due to a feeling that other students are competent at library use while they alone are incompetent.

- This lack of competence is somehow shameful and must be kept hidden.

- Asking questions reveals their inadequacies.

\section{Prescribed texts}

A discussion of strategy must include reference to the issue of prescribed texts.

An overwhelming number of students think the library should stock prescribed texts, mainly because of the expense of these books. Availability in bookshops is another reason and a few mention convenience.

In a text-centred course, the name of the game is treasure hunt, exacerbated by a general lack of resources. One of the first casualties is the notion of learning, and a sense of strategy focussed on gathering information. Research as a process and planned activity in terms of information and knowledge is reduced to a competitive exercise to get The Text.

In dealing with lack of access to prescribed texts, a negligible number said they would borrow from friends. Most 
would use another library and only $14 \%$ would consider alternative sources of information. In one group, $30 \%$ said they would photocopy the book. This was considerably more than in any other group and one wonders how a culture of photocopying develops in any one group.

The answers must be understood in the light of confusion over the meaning of 'prescribed', 'recommended' and 'relevant'. It would appear that only about a third of the students have a clear idea of what 'prescribed', 'recommended' or 'relevant' mean. The way prescribed is understood is disturbing because it indicates the test-orientation of students: 'text used for exam questions', 'text required to pass at the end of the year', a text that is 'extra to class readers'.

The answers to how do you search for information? Do you (options) ...? (B3) suggested that bibliographies were understood as the lecturers' reading list. Prescribed books are seen as necessary because 'they have the most important information'. Do students have this perception because the lecturer makes it so? It is questionable that in the management and social sciences at undergraduate level, any single book contains the most important information. This may be so for testing, but then that probably relates to the lecturer's convenience in testing and the administration of the department, more than the development of learning on the part of the student. However, providing alternative sources in the interests of increasing access may raise the problems Merkestein, quoted above, mentions.

It is clearly worthwhile investigating the design of a curriculum that doesn't need a textbook or reader, or a curriculum that relates to several basic textbooks. (How often do textbooks go out of date?) As long as there is this emphasis on prescribed texts, it will undermine efforts to inculcate a sense of strategy in students.

\section{Locus of control}

A sense of strategy assumes a certain sense of one's own power. In other words, it assumes that the person has an internal locus of control. Out of the entire sample of 770 about half, in response to the question 'what do you do when you can't find an item', said they would ask a librarian. Many others would ask other people for help. One cannot infer too much from this response - asking a librarian is the easiest and obvious thing to do. However, only about ten indicated an internal locus of control and sense of strategy in phrases such as 'change tactics', 'replan and find out what went wrong', 'relax, change my method and strategy' or by mentioning looking for alternatives. The sample was not controlled enough to prove that a sense of strategy developed in later years. A superficial impression is that such a sense does not develop in later years. Given this reliance on staff, the role of the staff bears further enquiry.

\section{Role of the staff}

I have mentioned the missionary dilemma that faces librarians. According to Isaacson (1983:65) the literature on
Library Inreach, which is the application of psychological techniques to the reference interview, 'reveals evidence of misguided philanthropic motivation, because it suggests that the librarian's primary responsibility is to provide counselling rather than information service'. He quotes Penland (1974: 71) who states that the librarian ought to be 'an agent of change or advocate and ombudsman in human affairs', and Thomas, Hinckley and Eisenbach (1981:72) who state that

'a reference librarian not only must be a master of research methodology and reference sources, but also must have the instincts of a social welfare worker'.

Suttie (1990:102) in discussing library and academic support strategies suggests that 'library staff should display distinctive qualities, namely an ability to empathize with the particular difficulties of the students'. But she specifically states that 'they should not have the typical missionary spirit', and that 'the most suitable librarians are those from the ethnic minorities themselves'. She goes to suggest a particular advantage that librarians have:

'Librarians have the advantage of being the "third party" in the educational encounter between lecturers and students. They are less threatening than lecturers because they are not the arbiters of academic success. They are therefore well placed to help users in their studies. They can be more encouraging and positive in their approach. They are also better able to maintain motivation among students by establishing a more personal and less formal relationship' (1990: 104).

The role of staff can be associated with locus of control and the services offered by the library. There are also cost implications. In answer to A8 $20-30 \%$ of students said that the librarian would 'take' them to the shelves or computer as opposed to 'direct' or 'tell' them where to go or what to do. In other words a quarter of the students are getting physical and time-consuming help for problems that could be addressed by signage and a focussed training course.

Koen (in discussion) says that students do not analyse the question and do not listen to instructions. The researcher attributes this to course overload and unfamiliar surrounding.

Koen confirms that students fail to realize that time is an important factor in the information-seeking process, and that students start seeking information one or two days prior to the due date of the assignment. Another librarian raises questions about her role (personal memorandum):

'A student of (discipline) seems to be under the impression that it is the task of the librarians to explain her assignment to her since she does not understand what the wording of the topic means. I tried to explain to her that it is her duty and the duty of her lecturer to make sure that she knows what it is she wants and needs before she comes to us' (emphasis added). 
There was an overwhelmingly positive attitude towards librarians, with some frustration with librarian assistants. The use of library assistants (students on the work-study programme) is a training opportunity and cost-saving measure not to be missed, but perhaps better use would be made of the opportunity if there were clearer roles and responsibilities and these were made clear to the students.

Based on discussions with the subject librarians, who were put under immense pressure to interpret assignments for students so that they could help the student find information, and to a lesser extent on the researcher's analysis of the essays, it was thought that for most students the biggest problem in doing an assignment was in understanding what was required. However, in response to when you struggle to do an assignment, where in the process do you experience big problems? (B11), most students said their biggest problem was in gathering information. The question arises of whether students discriminate between understanding what is required, expressing their requirements and gathering the information.

There are a range of questions to be asked about the reference question. Mount (1966:575) gives an example of a question asked at the reference desk which bears little resemblance to the question that should have been posed: 'do you have any recent literature on the design of radar circuits?' instead of 'do you have any information on the radar circuits used in the latest United States lunar spacecraft?' He lists the following barriers to an effective reference question:

An enquirer:

- lacks knowledge of the depth and quality of the collection;

- lacks knowledge of the reference tools available;

- lacks knowledge of the vocabulary used by a particular set of tools;

- does not willingly reveal his reason for needing the information;

- hasn't decided what he really wants;

- is not at ease in asking his question;

- feels that he cannot reveal the true question because it is of a sensitive nature;

- dislikes reference staff members; and

- lacks confidence in the ability of the reference staff.

These barriers need to be understood in light of Suttie's comments above. In terms of getting help to do an assignment, students, in response to: do you think the same person should help you through all stages of an assignment or do you think different people should help you through different stages? Who are these people? (C9), indicated a range of people, from lecturers, tutors, friends and librarians. Librarians were not featured significantly more than others.

Melllon has been quoted above on feelings in the library. The point is worth making again with reference to the role of librarians. Kulthau (1985:23) points out that:

'While the library research process appears to be quite simple and straightforward, the feelings of people within the process reveal its complexity. It can be a traumatic and threatening process. All kinds of irrational behaviour can surface. Acknowledging the succession of feelings people are likely to experience in a library search is the first step toward developing effective search strategies. Librarians who instruct students need to begin to incorporate an understanding of the sequence of feelings into any introduction to library sources'.

Nahl-Jacobovits and Jacobovits (1992:13) suggest specific instruction to develop skills in the affective domain:

- teaching users to accurately estimate the time they need to search for information;

- having intermediate due dates for parts of the assignment to eliminate procrastination;

- instructing users in common errors and their solutions so that they have more ways of problem solving as they learn to search; and

- acknowledging the increasing complexity of the information environment.

'We found that having students work in pairs on hands-on on (sic) conceptual exercises increases their involvement in learning. We attempt to build in success with the tools by breaking up the overall task into smaller, but still challenging steps: before execution; search planning sessions; distinguishing among and memorizing types of publications; asking students to list or map where they have been in the library.'

Nahl-Jacobovits and Jacobovits (1992:16) echo Morrow's point made in the introduction, when they say that

'freedom of access to information is not provided solely by making resources available in libraries, but by providing patrons with the affective, cognitive, and sensory motor library skills necessary to interact with information systems'.

Finally, in terms of librarians being able to provide instruction - if that is where the responsibility is to be located - Mellon (1988:137-138) makes the point with reference to school libraries, that:

'The problems seemed to be of understanding and structure rather than competence. Few people outside the field of librarianship have any idea of what librarians do ... thus they find it hard to convince teachers to give them the time and administrators to give them the support they need for effective library instruction ...

This problem is compounded by the current demand for accountability in public education ... Even the most competent and highly respected school librarian has trouble convincing the classroom teacher to give up a moment of instruction time'.

His points apply to universities. The whole question of the time it takes to train students and the time they need to think and plan points to the curriculum. Many academics visiting UWC have observed that the workloads are high, and I have quoted an example above. 
From a librarians point of view, Koen (in discussion) claims that:

'Lecturers definitely have responsibility to teach and develop critical skills, while librarians play a facilitating role in helping students apply those skills in the research process.

Library instruction is merely one way of reaching small groups of students as opposed to the one-onone interactions at the reference desk, in offices, and among the shelves'.

\section{Role of the computer}

The role of the computer in an overall strategy can be quite complex. In answer to the question 'when you already know what you want, how do you find it?' (C1) substantially more than half said they would use the computer. In response to the question 'how do you search for information?' (B3) up to 95\% said they would use the computer and very few browsed the shelves. Does this mean that the computer is functioning as signage? To what extent are students familiar with the classification of their subject and know the library layout and can go direct to the shelves? To what extent is the computer the search strategy, rather than being part of a previously thought-out research strategy. In response to A7 (finding out where something is in the library), very few mention searching shelves - they ask staff, friends, packers or tutors.

This issue is an example of the interrelatedness of problems in the library. There may well be an insufficient number of terminals, but there may also be unnecessary pressure on terminals leading to queues and noise.

In any event the use of computers needs to be addressed more broadly.

Manie (1994) has pointed out that there was - at that stage - no national strategic plan for the implementation of IT in education in South Africa. His comments are worth noting in light of Merrett's comments (1988) quoted above about libraries 'full of gleaming hardware acquired at great cost' when the 'fruits of the latest scholarship and investigation in book format is being eroded to a level of disastrous proportions'. (In that same report Doust questions the validity of library computerization and demolishes the assumption that there is an ideological neutrality about computerization.) In this context Manie (1994:2) writes:

'Information technology in education, while being regarded by many as a luxury that a democratic South Africa cannot afford, is too powerful and pervasive a phenomenon to be ignored in a modern information society such as ours. Furthermore, education deals with, among other things, creating opportunities for students to acquire the necessary social and critical skills and in order to cope with the challenges of society and to transform it'.

The process relies on the people, not the technology itself, but Manie perhaps goes too far when he suggests that computers are simply tools which can amplify the power people have and the social relations in which they engage. The issue of actual as opposed to formal access remains.

The debate is taken further by McClure (1994) with specific reference to networks and the role of libraries. He points out 'an educational disconnect between the rapidly developing communications technologies and the information resources available to the public, and the public's ability to use these resources' and also the fact that the educational system remains largely oblivious. He states specifically (1994:115):

'Network literacy - the ability to identify, access, and use electronic information from the network - will be a critical skill for tomorrow's citizens if they wish to be productive and effective in their personal and professional lives'.

He goes on to expand the notion of literacy to include the ability to locate, process and use information effectively regardless of delivery mechanisms and the type of format in which that information appears (his emphasis, 1994:117). The complications are enormous, for 'even those who are creating the networked society cannot predict how it will evolve' (1994:119).

In developing his argument for reinventing education and libraries for a networked society, McClure quotes Papert (1993:50):

'School will either change radically or simply collapse. It is predictable (though still astonishing) that the Education Establishment cannot see farther than using new technologies to do what it has always done in the past: teach the same curriculum ... I would go further: the possibility of freely exploring worlds of (electronic) knowledge call into question the very idea of an administered curriculum'.

Libraries in South Africa, dealing with the historical legacy of apartheid, must take heed from the lessons of the US where, according to McClure, 'various population segments are disenfranchised from accessing information due to race, gender, income, location and a host of other reasons' and thereby being ensured second-class status in the society. Once again, this time in the context of computers, we have to return to the issue of curriculum. We also, if Papert is correct, have to encourage the use of wider resources.

\section{Wider use of resources}

Almost $90 \%$ of the UWC students surveyed never make use of interlibrary loans but almost $90 \%$ often make use of short loans. There are several other tertiary institutions in the Cape and many municipal and community libraries. Less than $20 \%$ of the students make use of these resources. This is not surprising considering the transport infrastructure and the number of up-country students in residence. Also, predictably enough, the range of libraries used increases with the seniority of the student. The point here is the awareness of, and access to, alternative libraries as part of broad sense of strategy. Most HBUs are isolated from towns or cities, and are often the most highly resourced entities in their communities. 
These points relate to Suttie's (1990:103) observation of university libraries as public libraries:

'It is clear then that the university library has to cater for the needs of its student body and the community from which it comes, not in a narrow sense of providing an ethnocentric service within broadly Western European parameters, but rather by means of a dramatic rethink of its total functioning in the South African context. The role of the library is therefore crucial as an agency of social change; by meeting the needs of its students, it initiates a "revolution" in the provision of information that emphasizes its influence as an opinion former. The academic library thus interacts with the intellectual community, stimulating new knowledge, and because of its user-friendliness and its increasing relevance to the needs of disadvantaged users, it invites an improvement in educational techniques'.

From a different point of view, and given the use of public libraries by UWC students, it needs to be remembered that public libraries have a service orientation different to that of academic libraries. The discussion of electronic media in the previous section also relates to the use of wider resources.

\section{Making notes and photocopying}

A discussion of the role of making notes in the learning process is beyond the scope of this article. The issue, however, relates to a search strategy, the use of prescribed texts and photocopying, and hence to the use of the library.

Only slightly more than half the students said they used a book for more than three days. Some seemed to think it was wrong to do so. Obviously if there is a prescribed text and it is on short loan/reserve and the curriculum demands access to exactly that book and only that book which is prohibitively expensive or unavailable, students will photocopy. In answer to the question which do you rely on more, making notes or photocopies? (C10) less than a quarter of the students make notes rather than photocopies to take home. The main reason for making copies was that it took less time than making notes. There was little evidence of the notion of notetaking as part of a learning process.

Again we return to curriculum design. Notetaking is time consuming, but it is the difference between processing and 'having' information.

\section{Noise}

The issue of noise subsumes several others such as socializing, doing group work and cultural perceptions of noise to name just a few. I realize that the many references to specific conditions in the UWC library may be of limited interest to a wider audience, but they are mentioned to indicate how problems which may loom large in the eyes of the casual observer, are not the real ones. In fact, they serve to cloud the nature and source of the actual problems.
Noise is commonly perceived as the biggest single problem in the UWC library. However, answers to the questionnaires revealed that only $35 \%$ of students rate it as the first problem, and when second-order problems are taken into account, the figure rises to 55\%. Noise arises because of co-working, study space and queues at terminals and photocopiers.

With respect to noise it is worth noting that at least one or two students in almost every group of essays (72a, 97b, 98b, 140c, 163d) stated that they used the library because it was quiet. Often a single student will state that he/she uses the library because it is quiet, or that it isn't quiet but should be, and that it is where he/she meets to discuss work. Essay (156d) is typical in this respect:

'The noise level has proved very distracting and seems to have developed into a culture which no one seems to bother about correcting. The situation seems to be getting worse day by day as more noisemaking is reinforced'.

In response to the question would you tell another student to be quiet? (B8), the issue of whether or not first years are less distracted by noise arose. Later-year students tend to more direct confrontation. Overall more than $50 \%$ of students would directly confront noisemakers, while several students said they would not, and their reasons reveal the cultural/ ideological nature of noise: 'his democratic right to make a noise', and, 'his/her freedom to talk'.

It needs to be borne in mind that noise is a relative and subjective experience, both on an individual and group level. Several times, in the essays and the questionnaires, a student of one group considered it worthwhile identifying the cultural group of noisemakers.

Usually students identified fellow students as the main source of noise, but staff are also identified as noisemakers:

'Noise from the students is disappointing, it also comes from the staff especially in level 6 , they would laugh and make some jokes while we are busy studying. I was surprised to notice that they don't respond to a plea from their fellow worker one time' (58).

\section{Socializing and working}

Noise is obviously not the only problem, given that several students identified the library as a place to meet friends and socialize. Whilst some of the comments are hopefully tongue in cheek, such as

'(the library) is the place to look for new girl friends especially those who are new at the campus and unable to use terminals and photocopying machines ... the stairs at the back are the place to make love' (52), many students do perceive socializing as an acceptable activity in the library.

The kind of socializing is not just light-hearted distraction. One aspect of the problem is the type of work done in the library: 
'Also fun to work with your friends and fellow students in the library because one helps one another with work you do not understand. The noise level on certain levels can sometimes be irritating' (77a).

Perhaps certain areas could be set aside as work areas. Given the fact that students are increasingly required to do group projects, and taking into account the home circumstances of many students, it is not surprising that pressure is being put on the library to provide working space for groups.

The need to address this becomes more clear as research, quoted above, emphasizes the usefulness of 'noisy' techniques in learning library skills, such as talking through, handson activity and group work.

One student provided an interesting insight into the social use of the library:

'Once you start using the library often you meet people of different cultures and you start conversing with them. In this way one can say that UWC's library for that matter breaks that barrier that the apartheid regime has instilled in us, in the sense that the cultural barrier is being broken down by using the library, by learning about people and the way they live, et cetera' (96b).

Another student pointed out that the library is the place where students come to exchange information that they have gathered (93b), which could be in fact quite an insight into the true nature and purpose of libraries.

The response of students to seeing another student tear a page out of book (A10) was varied. Most stated they would report the students (rather than confront), mainly because it deprives other students. As one student put it, it is 'privatizing information'.

Responses to the general state of the library also indicates cultural and/or class perceptions. One student stated the 'building is spectacular, especially the girls' toilets' (148d) with two others mentioning dirtiness, specifically the toilets $(51,63)$.

Finally, knowledge about the library can be inversely related to complaints, since the student is more able to find ways round the problems presented, such as finding the quiet places (151d) and understanding the arrangement of information and thereby facilitating searches (156d). There are two implications here. One is that 'no complaint' does not necessarily mean 'no problem'. The student may feel that she or he has solved a difficulty, but may be using an extremely inefficient method of doing so. Another implication is that students may feel that they are responsible for not knowing how to use the library and therefore they have no right to complain, or even worse, that they are unable to perceive or define exactly what the problem is that they are facing.

\section{Conclusion}

The basic conclusion of this article is that any library education programme needs to extend beyond the library and be a holistic effort entered into by a range of players.
Curriculum design is a major factor that militates against the effective use of the library. We need to design curricula that takes into account actual as opposed to formal access that students have to knowledge, the institution and its facilities. The following ordering of problems are proposed:

First-order problems centre on the curriculum and the use of prescribed texts and an overloaded content. At this level the relationship between library and teaching staff is important.

The second-order problems centre on broad educational issues; educating lecturers about their students, the research process and setting of assignments; basic education of students about information, libraries and electronic media; addressing the affective aspects of education; educating library staff about how students learn.

The third-order problems centre on practical issues in specific libraries: signage, noise, staff training, a user-friendly computer system, stock management, and practical communication between library and teaching staff.

A strategy of library education needs to address the problems that students have when they encounter these problems - expertise in wall climbing is of very little use if you are climbing the wrong wall. It does not matter how good a course in bibliographic instruction is if it only addresses third- or second-order problems that students have in using the library and never reaches first-order problems. Efforts to improve students' use of the library that begin with the thirdorder problems are wasteful, unless they reach the first-order problems. However, they rarely do so. Ideally, efforts should begin with the first-order problems.

\section{Acknowledgement}

I gratefully acknowledge the practical help and many insights of librarians at the University of the Western Cape, especially Zona Koen, and librarians at the University of Cape Town.

\section{References}

Behrens, S.J. 1990. Cross-cultural communication in the reference encounter: a South African perspective. South African journal of library information science, 58(1):87-97.

Blakey, E. \& Spence, S. 1990. Thinking for the future. Emergency librarian, 17(5):11-14.

Cleaver, B.P. 1987. Thinking about information: skills for lifelong learning. School library media quarterly, 16(1):29-38.

Cronin, B. \& Martin, I. 1983. Social skills training in librarianship. Journal of librarianship, 15(2): 105-122.

Crow, T. 1992. Critical thinking in the research process. School libraries in Canada, 12(2):32-37.

De Jager, K. 1991. Whom do we serve? User perceptions in a South African university library. South African journal of library and information science, 59(4):276-281.

Egerton, J. 1969. State universities and black Americans: an inquiry into desegregation and equity for negroes in 100 public universities. Atlanta: Southern Education Foundation.

Isaacson, D. 1983. Library inreach. $R Q, 23(1): 65-73$.

Josey, E.J. 1971. The role of the academic library in serving the disadvantaged student. Library trends, 20(2):432-444. 
Kemmis, S. \& McTaggert, R. 1988. The action research planner. 3rd ed. Geelong: Deakin University Press.

Krapp, J.V. 1988. Teaching research learning skills: a critical thinking approach. School library journal, 34(5):32-35.

Kuhlthau, C. 1989. Information search process: a summary of research and implications for school library media programs. School library media quarterly, 18(1):18-25.

Kuhlthau, C. 1985 . Feelings in the library research process. Arkansas libraries, 42(June):23-26.

Manie, A. 1994. Education policy on computers-in-education. A discussion paper. Presented at National Workshop: Policy and Planning in Provincial Post-Compulsory Education, University of the Orange Free State, 14-15 September. Bloemfontein: UOFS.

McClure, C. 1994. Network literacy: a role for libraries? Information technology and libraries, 13(2):115-125.

McCracken, G. 1988. The long interview. Beverley Hills, CA: Sage. (Sage University Paper Series on Qualitative Research Methods Vol 13.)

Mellon, C.A. 1988. Attitudes: the forgotten dimension in library instruction. Library journal, 113(14): 13-79.

Merrett, C. 1988. South African librarianship in crisis: alternative viewpoints. Wits journal of librarianship and information science, 5(July):124-132.

Morrow, W. 1992. Teaching large classes in higher education: address at the University of the North, December.

Mount, E. 1966. Communication barriers and the reference question. Special libraries, 57(8):575-578.

Nahljakobovits, D. \& Jacobovits, L.A. 1992. A content analysis method for developing uses-based objectives. Research strategies, 10(1):4-16.

Olsen, J. 1990. Education for thinking. Perspectives, 22(3):14-24.

Papert, S. 1993. Obsolete skill set: the 3Rs: literacy and letteracy in the media ages. Wired, May-June:(5):50.

Penland, P. 1974. Communication science and technology. New York: Dekker.

Rankin, V. 1988. One route to critical thinking. School library journal, 34(5)28-31.

Rosen, R. 1977. Psychobabble. New York: Atheneum.

Ruth, D.W. 1993. First fruits: what it is like to come to UWC, in $A D$ dialogues Vol. 1: explorations in change: case studies in academic development, ed. M. Walker, N. Badsha. Bellville: University of the Western Cape, Academic Development Centre.

Suttie, M.L. 1990. Libraries and academic support strategies in South African universities. South African journal of library and information science, 58(1):98-107.

Thomas, D.M., Hinckley, A. \& Eisenbach, E.R. 1981. The effective reference librarian. New York: Academic Press.

Walker, M. \& Badsha, N. 1993. Academic development and the challenge of curriculum change at the University of the Western Cape: an overview, in $A D$ dialogues Vol. 1: explorations in change: case studies in academic development, ed. M. Walker, N. Badsha. Bellville: University of the Western Cape, Academic Development Centre.

\section{Appendix A: questionnaires}

All three questionnaires asked for the following information from students:

\section{Questions to students}

Year of first registration

Degree for which registered

Part-time

Full-time
Home language

Do you live in residence

Do you live in digs

Do you live at home

To be noted by distributor of questionnaire:

Course

Level/year

Module

Day of week and date

Time of day

\section{Questionnaire A}

1. What is a library?

2. How often do you use the library? never occasionally once a week twice a week every day Why?

3. Do you think the library should stock prescribed books? Why?

4. What was your experience of libraries before coming to UWC?

5. What other libraries do you use?

6. How often do you make use of the short-loan collection special collections interlibrary loan the audiovisual facilities never 1-2-3-4-5 often never 1-2-3-4-5 often never 1-2-3-4-5 often never 1-2-3-4-5 often

7. How do you found out where something is in the library?

8. What do the librarians do when you ask them to help you? Try and describe in detail what they actually do, don't just say they help you find the book.

9. What are the four major steps you would take to improve the library?

1 .

2 .

3.

4

10. What would you do if you saw a student tearing a page out of a book? Why?

\section{Questionnaire B}

1. Why do you use the library?

2. What was your experience of libraries before coming to UWC?

3. How do you search for information? Do you use the bibliographies in what you already have browse through periodicals browse through book stacks browse through journals ask a librarian ask a fellow student use the computer go to other libraries 
4. What services does the UWC library offer besides keeping books and journals?

5. List, in order of importance, the four major problems you have in the library.

1 .......

2

3.

4

6. Are there study areas elsewhere on campus? If so, to what extent do you use them and why?

7. Where do you do most of your individual studying?

8. Would you tell another student to be quiet? Why?

9. What subject gives you the most problems in using the library?

10. What do you understand by prescribed, recommended and relevant material?

11. When you struggle to do an assignment, where in the process do you experience the big problems; understanding what is expected, gathering the information, writing it up, presenting it on time, or elsewhere?

\section{Questionnaire C}

1. When you already know what you want, how do you find it?

2. What do you do when you can't find an item?

3. How do you deal with lack of access to prescribed texts?

4. What physical aspects of the library please you or disturb you the most? Say why.

5. How did you learn about using the library?

6. What subject gives you the most problems in using the library?

7. Do you use books for more than three days? How often? Why?

8. What do you understand by prescribed, recommended and relevant material?

9. Completing an assignment means going through different stages. Do you think the same person should help you through all the stages of the assignment or do you think different people should help you through different stages? Who are these people?

10. Which do you rely on more;

i. making notes from books and journals or

ii. making photocopies to take home? Why?
Appendix B: distribution of questionnaires

\begin{tabular}{|c|c|c|c|}
\hline & $\begin{array}{c}\text { Department of Public } \\
\text { Administration } \\
\text { (PUA) }\end{array}$ & $\begin{array}{l}\text { Dept of Management } \\
\text { formerly Bus Econ } \\
\text { (BE) }\end{array}$ & $\begin{array}{c}\text { Industrial Psycho- } \\
\text { logy } \\
\text { (BPS) }\end{array}$ \\
\hline \multicolumn{4}{|l|}{ 1st year } \\
\hline \multirow[t]{3}{*}{ Full-time } & PUA 112 A (7) & BE111 A (128) & \\
\hline & $\mathrm{B}(15)$ & $B(103)$ & \\
\hline & $\mathrm{C}(14)$ & $\mathrm{C}(88)$ & \\
\hline \multirow[t]{3}{*}{ Part-time } & PUA 112 A (22) & & \\
\hline & B (7) & & \\
\hline & $\mathrm{C}(5)$ & & \\
\hline \multirow[t]{3}{*}{ 2nd year } & PUA 211 A (32) & BE 231 A (53) & \\
\hline & B (28) & $\mathrm{B}(56)$ & \\
\hline & $C(27)$ & $\mathrm{C}(59)$ & \\
\hline \multirow[t]{9}{*}{ 3rd year } & & BE 312 A (7) & \\
\hline & & B (3) & \\
\hline & & $\mathrm{C}(5)$ & \\
\hline & & BE 313 A (19) & \\
\hline & & $\mathrm{B}(19)$ & \\
\hline & & $\mathrm{C}(16)$ & \\
\hline & & BE 315 A (9) & \\
\hline & & B (8) & \\
\hline & & $\mathrm{C}(5)$ & \\
\hline \multirow[t]{3}{*}{ Honours } & & & BPS 701 A (9) \\
\hline & & & B (8) \\
\hline & & & $C(8)$ \\
\hline \multirow[t]{3}{*}{ Masters } & PUA M A (5) & & \\
\hline & B (13) & & \\
\hline & $\mathrm{C}(2)$ & & \\
\hline \multirow{4}{*}{\multicolumn{2}{|c|}{ Number of questionnaires }} & A & 291 \\
\hline & & $\mathrm{B}$ & 250 \\
\hline & & $\mathrm{C}$ & 229 \\
\hline & & Total & 770 \\
\hline
\end{tabular}

